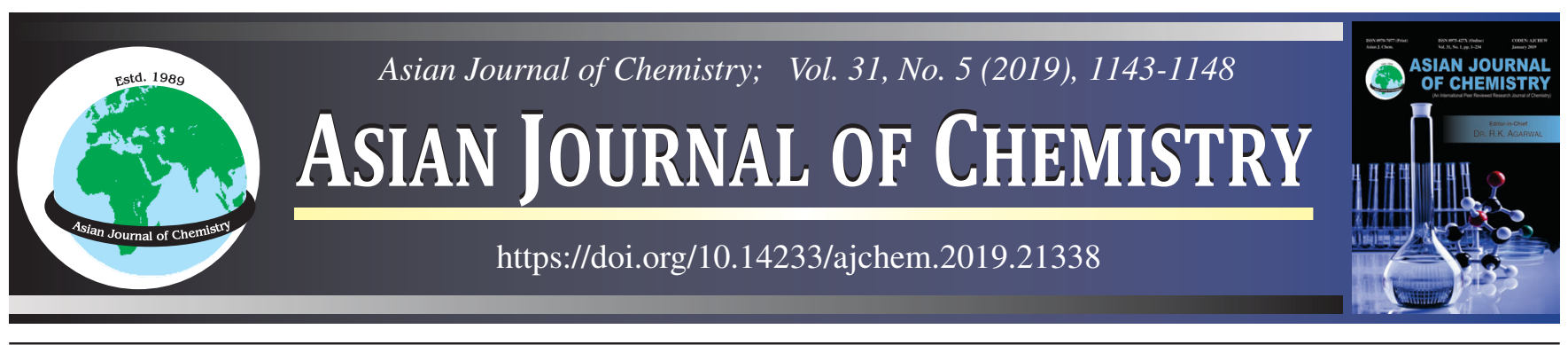

\title{
GC-MS Profile of Volatile Oils Extracted from Jatropha multifida L. using Hydrodistillation and Solvent-Free Microwave Extraction Methods
}

\author{
O.A. Wintola*,®e, E.O. Ajayi and A.J. Afolayan ${ }^{\circledR}$
}

Medicinal Plants and Economic Development (MPED) Research Centre, Department of Botany, University of Fort Hare, Alice 5700, South Africa

*Corresponding author: Fax: +27 866282295; E-mail: owintola@ufh.ac.za

Received: 20 March 2018;

Accepted: 30 January 2019;

Published online: 28 March 2019;

AJC-19345

Volatile oils were extracted from the leaves of Jatropha multifida using solvent free microwave and hydrodistillation methods and the oils obtained were analyzed by gas chromatography-mass spectrometry (GC-MS). The major compound as observed is eucalyptol with 70.38 and $35.62 \%$ for solvent-free microwave extraction (SME) and hydrodistillation extraction (HDE), respectively. The oil compositions were dominated by oxygenated compounds. Oxygenated monoterpenes were prevalent in contrast to monoterpenes hydrocarbons. The | oils were also characterized by oxygenated sesquiterpenes (SME, $6.05 \%$; HDE, $7.34 \%$ ). This study may provide information on a suitable method of extraction of the essential oil for industrial application and may assist in the realization of the essential oil as a natural source of plant and animal food additives. These various bioactive compounds in the essential oil may partially justify their use in folklore medicine.

Keywords: Jatropha multifida, Hydrodistillation, Solvent-free microwave, Extraction, GC-MS.

\section{INTRODUCTION}

Essential oils obtained from plant have recently gained a great popularity and scientific interest till date. It is recognized to be used, not only as food additives, but also in aroma therapy, antitumor therapy, as potential antimicrobial agents against multi-resistant bacteria and in other purposes in medical and non-medical fields [1]. In recent years scientists all over the world have motivated for the food and chemical industry to primarily depend on the use of essential oils and their application in food preservation and drug formulations. This is because essential oils are natural additives which extend the shelf-life of products, thereby preventing the risks of continuous increase of negative consumer perception of most synthetic preservatives [2,3]. Plants and their derivatives have long been used as both drugs and dietary supplements by man. The myriad uses of compounds from plants reflect a global trend towards the increased consumption of natural products. A number of medicinal benefits exhibited by herbs belonging to the genus Jatropha of Euphorbiaceae family are reported [4]. Plants are rich sources of secondary metabolites and have been found to have pharmacological properties [5].
Jatropha species (Euphorbiaceae family) are non-edible multi-purpose, drought resistant perennial shrubs. They occur mainly in the tropical parts of the world and consist of about 170 species although the origin is uncertain, they are believed to be indigenous to Barbados. They are found in the IndoMalayan region, tropical America, tropical Africa and some subtropical countries like South Africa, Madagascar and Mauritius [6]. In their uncultivated state, these non-food wild species grow around the island in backyards and in the wild [5]. Jatropha species have, however, been properly domesticated in some regions and as a result their productivity is variable and the long-term impact of their large-scale use is unknown [7].

Jatropha multifida Linn mostly called 'coral plant' is a shrub with smooth grey barks, which exudes whitish coloured watery latex when cut [8]. This species grows throughout the tropics as an ornamental plant and normally grows to attain a height between 3 and 7 feet. It grows well in the tropics and can thrive in almost every kind of soil $[8,9]$. The roots, stems, leaves, seeds, latex and oil of the plant have been widely used in Africa, Asia and Latin America in folk medicine to cure various ailments like thrush on tongues of babies, oral candidiasis,

This is an open access journal, and articles are distributed under the terms of the Creative Commons Attribution-NonCommercial-ShareAlike 4.0 (CC BY-NC-SA 4.0) International License which allows readers to freely read, download, copy, distribute, print, search, or link to the full texts of its articles and to use them for any other lawful non-commercial purpose as long as the original source is duly acknowledged. 
gonorrhoea, fever, astriction, wounds, skin infections and as purgative [10-13]. Several studies have revealed the efficacy of J. multifida against a wide array of bacteria and fungi [5,1416]. J. multifida is used in Nigerian folk medicine for the treatment of parasitic infections, cancer and hepatitis [17]. Previous studies conducted in Tanzania have shown that Jatropha multifida has significant antifungal activity, against many species of Candida, but little against Candida albicans [18]. Some traditional practitioners have also reported the successful application of J. multifida as remedies against hepatitis and leishmaniasis [19].

Several studies have reported isolated compounds from J. multifida [20-22]. Compounds include diterpenoid, multidione, multifidone, multifolone and $(4 E)$-jatrogrossidentadione acetate have been isolated from the stems of J. multifida along with five known diterpenoids, a flavone and a coumarinolignoid from detailed analysis of 1D and 2D NMR spectra and X-ray crystallographic analysis [20,21,23]. Cyclic peptides (labaditin and biobollein) isolated from the latex of J. multifida have also been reported [22,24]. In addition, some compounds such as (2-methylbutyryl) phloroglucinol and 1-[(2-methylbutyryl)phloroglucinyl- $\beta$-D-glucopyranoside from the latex of J. multifida have been reported [25]. In view of all the reports on Jatropha multifida crude and oil extract, there is no report on the effect of extraction methods on the chemical constituents of the essential oil of Jatropha multifida leaves. Hence, this study aimed to assess the effect of extraction methods on the chemical constituents of the essential oil of Jatropha multifida leaves.

\section{EXPERIMENTAL}

Mature fresh leaf samples were collected from Durban University of Technology botanical garden in KwaZulu Natal province of South Africa. A sample of the plant specimen was identified by Prof. D.S. Grierson, a botanist in the department of Botany, University of Fort Hare. Sample specimen (Win 01/15) was deposited in the Giffen's herbarium of the university. The fresh plant materials were cleaned washed under running tap water, later distilled water and eventually weighed.

Hydrodistillation extraction (HDE) of the essential oil of the fresh leaves of Jatropha multifida: $40 \mathrm{~g}$ of fresh Jatropha multifida leaves were weighed into a $5 \mathrm{~L}$ glass HDE apparatus containing $3 \mathrm{~L}$ of sterile distilled water. The extracted essential oil was retained in $1 \mathrm{~mL}$ hexane used as solvent phase in the oil collector column of the hydrodistillation apparatus. The extraction was done for $3 \mathrm{~h}$. Thereafter, the essential oil was carefully separated into an Amber glass sample vial and kept in the refrigerator at $4{ }^{\circ} \mathrm{C}$ prior to chemical analysis. The essential oil yield was calculated using the formula:

$$
\text { Oil yield }(\%)=\frac{\text { Weight of oil extracts }}{\text { Weight of sample }} \times 100
$$

Solvent-free microwave extraction (SME) of the essential oil of the fresh Jatropha multifida leaves: $40 \mathrm{~g}$ of fresh Jatropha multifida leaves were weighed into the reactor of an automatic millstone dry DIST microwave apparatus. The multimode microwave reactor has a twin magnetron $(2800 \mathrm{~W}$, $2450 \mathrm{MHz}$ ) with a maximum delivered power of $1000 \mathrm{~W}$ in
$10 \mathrm{~W}$ increments. A rotating microwave diffuser ensures homogenous microwave distribution throughout the plasma-coated polytetrafloroethylene (PTFE) cavity $(35 \mathrm{~cm} \times 35 \mathrm{~cm} \times 35 \mathrm{~cm})$. The temperature was monitored by a shielded thermocouple (ATC-300) inserted directly into the corresponding container. Temperature was controlled by a feedback to the microwave power regulator, which indicated that the initial temperature was $20^{\circ} \mathrm{C}$ and increased at $7.5^{\circ} \mathrm{C} / \mathrm{min}$ up to $100{ }^{\circ} \mathrm{C}$ before commencement of essential oil extraction for $10 \mathrm{~min}$. After complete extraction of the oil, the temperature decreased at $7.0^{\circ} \mathrm{C} / \mathrm{min}$ until $30^{\circ} \mathrm{C}$ was reached. The total running time of the extraction process was $30 \mathrm{~min}$. The extracted essential oil was retained in $1.0 \mathrm{~mL} n$-hexane used as solvent phase in the oil collector column of the equipment. Afterwards, the essential oil was carefully separated into an Amber glass sample vial and kept in the refrigerator at $4{ }^{\circ} \mathrm{C}$ for further analysis.

Determination of chemical composition of the essential oil of leaves of Jatropha multifida: The leaf oil of Jatropha multifida was analyzed with an Agilent 6890N gas chromatograph (GC) coupled to Agilent 5975 mass selective detector (MSD) with a Zebron-5MS column (ZB-5MS $30 \mathrm{~m} \times 0.25$ $\mathrm{mm} \times 0.25 \mu \mathrm{m})(5 \%$ phenyl methyl polysiloxane) (California, USA). The following column and temperature conditions were used: $\mathrm{GC}$ grade helium at a flow rate of $2 \mathrm{~mL} / \mathrm{min}$ and splitless $1 \mathrm{~mL}$ injections was used. The injector, source and oven temperatures were set at 280,280 and $70^{\circ} \mathrm{C}$, respectively. The ramp settings were; $15^{\circ} \mathrm{C} / \mathrm{min}$ to $120^{\circ} \mathrm{C}$, then $10^{\circ} \mathrm{C} / \mathrm{min}$ to $180^{\circ} \mathrm{C}$, then $20^{\circ} \mathrm{C} / \mathrm{min}$ to $270{ }^{\circ} \mathrm{C}$ and held for $3 \mathrm{~min}$ while ionization energy was $70 \mathrm{eV}$.

Qualitative identification of the different constituents of the essential oil was determined by their GC retention times, percentage composition (area \%) and retention indices. The interpretation and identification of their mass spectra was confirmed by mass spectral incorporated library. The identification was further confirmed by search using the National Institute of Standards and 35 Technology (NIST) database (NIST/EPA/NIH mass spectral library 2014) with those of published data. Empirical searches were conducted using The PubChem Project (https://pubchem.ncbi.nlm.nih.gov/) and DrugBank (www.drugbank.ca/) to identify the known pharmacological properties associated with these compounds. The relative amount (RA) of an individual component of the essential oil was expressed as a percentage of the peak area relative to the total peak area. The method of Kováts [26] modified by IUPAC [27] was adopted in the calculation of Kováts indices (KI) of the components relative to the RT of a series of $n$ alkanes with linear interpolation on the HP-5MS column.

\section{RESULTS AND DISCUSSION}

Chemical composition of the essential oil: The yields, retention indices and chemical compositions of the essential oil of Jatropha multifida leaves obtained by different methods of HDE and SME are indicated in Table-1, while the corresponding spectral peaks for the different extraction methods are shown in Fig. 1. A total of 61 chemical components that could contribute to the medicinal property of the plant were identified in both methods of extraction. The yields of a colourless volatile oil of HDE and SME were 1.0021 and $0.3136 \%$ 
CHEMICAL COMPOUNDS OF THE ESSENTIAL OIL OFJatropha multifida Linn. LEAVES

\begin{tabular}{|c|c|c|c|c|c|c|}
\hline \multirow{2}{*}{ No. } & \multirow{2}{*}{ Chemical constituent } & \multirow{2}{*}{$\begin{array}{l}\text { Kovat } \\
\text { index }\end{array}$} & \multicolumn{2}{|c|}{ Peak areas $(\%)$} & \multirow{2}{*}{ Formula } & \multirow{2}{*}{ m.w. } \\
\hline & & & SME & HDE & & \\
\hline 1 & (-)- $\alpha$-Pinene & 943 & 2.64 & 0.05 & $\mathrm{C}_{10} \mathrm{H}_{16}$ & 136 \\
\hline 2 & $\beta$-Myrcene & 962 & - & 0.07 & $\mathrm{C}_{10} \mathrm{H}_{16}$ & 136 \\
\hline 3 & 2,4-Heptadienal, $(E, E)$ - & - & - & 0.06 & $\mathrm{C}_{7} \mathrm{H}_{10} \mathrm{O}$ & 110 \\
\hline 4 & $o$-Cymene & 980 & 8.11 & 0.85 & $\mathrm{C}_{10} \mathrm{H}_{14}$ & 134 \\
\hline 5. & Eucalyptol & 984 & 70.38 & 35.62 & $\mathrm{C}_{10} \mathrm{H}_{18} \mathrm{O}$ & 154 \\
\hline 6. & Ethyl 2-(5-methyl-5-vinyltetrahydrofuran-2-yl)propan-2-yl carbonate & 1023 & - & 0.11 & $\mathrm{C}_{13} \mathrm{H}_{22} \mathrm{O}_{4}$ & 242 \\
\hline 7. & 2-Nonanone & 1003 & - & 0.05 & $\mathrm{C}_{9} \mathrm{H}_{18} \mathrm{O}$ & 142 \\
\hline 8 & 2-Carene & 1005 & - & 0.36 & $\mathrm{C}_{10} \mathrm{H}_{16}$ & 136 \\
\hline 9 & $1,3,8-p$-Menthatriene & 1014 & - & 2.24 & $\mathrm{C}_{10} \mathrm{H}_{14}$ & 134 \\
\hline 10. & Bicyclo[2.2.1]heptan-2-ol, 1,3,3- trimethyl-, (1R-endo)- & 1016 & 1.35 & 0.09 & $\mathrm{C}_{10} \mathrm{H}_{18} \mathrm{O}$ & 154 \\
\hline 11. & trans-p-Mentha-2,8-dien-1-ol & 1017 & - & 0.13 & $\mathrm{C}_{10} \mathrm{H}_{16} \mathrm{O}$ & 152 \\
\hline 12 & $L$-Pinocarveol & 1027 & - & 0.74 & $\mathrm{C}_{10} \mathrm{H}_{16} \mathrm{O}$ & 152 \\
\hline 13 & Furan, tetrahydro-2,5-dipropyl- & 1030 & - & 0.11 & $\mathrm{C}_{10} \mathrm{H}_{20} \mathrm{O}$ & 156 \\
\hline 14 & 4-Isopropenylcyclohexanone & 1044 & - & 0.16 & $\mathrm{C}_{9} \mathrm{H}_{14} \mathrm{O}$ & 138 \\
\hline 15 & 2-Ethyl furan & - & - & 1.17 & $\mathrm{C}_{6} \mathrm{H}_{8} \mathrm{O}$ & 96 \\
\hline 16 & trans-p-mentha-1(7),8-dien-2-ol & 1044 & 1.82 & 3.45 & $\mathrm{C}_{10} \mathrm{H}_{16} \mathrm{O}$ & 152 \\
\hline 17 & $\alpha$-Terpineol & 1045 & 1.98 & 0.18 & $\mathrm{C}_{10} \mathrm{H}_{18} \mathrm{O}$ & 154 \\
\hline 18 & cis-Carveol & 1055 & 0.46 & 0.62 & $\mathrm{C}_{10} \mathrm{H}_{16} \mathrm{O}$ & 152 \\
\hline 19 & cis-p-mentha-1(7),8-dien-2-ol & 1059 & 2.41 & 4.67 & $\mathrm{C}_{10} \mathrm{H}_{16} \mathrm{O}$ & 152 \\
\hline 20 & $D$-Carvone & 1244 & 0.43 & 0.95 & $\mathrm{C}_{10} \mathrm{H}_{14} \mathrm{O}$ & 150 \\
\hline 21 & Pinocarvone & 1036 & 0.95 & - & $\mathrm{C}_{10} \mathrm{H}_{14} \mathrm{O}$ & 150 \\
\hline 22 & Terpinen-4-ol & 1041 & 0.65 & 0.69 & $\mathrm{C}_{10} \mathrm{H}_{18} \mathrm{O}$ & 154 \\
\hline 23 & $\left(4 \mathrm{R}^{*}, 5 \mathrm{R}^{*}, 9 \mathrm{~S}^{*}\right)-5,9$-Dimethylspiro[3. 5]nonan-1-one & 1074 & - & 0.09 & $\mathrm{C}_{11} \mathrm{H}_{18} \mathrm{O}$ & 166 \\
\hline 24 & Thymol & 1075 & 0.72 & 2.54 & $\mathrm{C}_{10} \mathrm{H}_{14} \mathrm{O}$ & 150 \\
\hline 25 & Phenol, 2-ethyl-4,5-dimethyl- & 1090 & - & 0.28 & $\mathrm{C}_{10} \mathrm{H}_{14} \mathrm{O}$ & 150 \\
\hline 26 & 2-Octenoic acid, 4-isopropylidene-7-methyl-6-methylene-, methyl ester & 1092 & - & 0.31 & $\mathrm{C}_{14} \mathrm{H}_{22} \mathrm{O}_{2}$ & 222 \\
\hline 27 & 2-Oxabicyclo[2.2.2]octan-6-ol, 1,3,3-trimethyl-, acetate & 1104 & 0.33 & 0.10 & $\mathrm{C}_{12} \mathrm{H}_{20} \mathrm{O}_{3}$ & 212 \\
\hline 28 & $\alpha$-Campholenal & 1115 & - & 0.16 & $\mathrm{C}_{10} \mathrm{H}_{16} \mathrm{O}$ & 152 \\
\hline 29 & $\beta$-Phenylethyl butyrate & 1119 & - & 0.11 & $\mathrm{C}_{12} \mathrm{H}_{16} \mathrm{O}_{2}$ & 192 \\
\hline 30 & Cyclohexane, 1-ethenyl-1-methyl-2,4-bis(1-ethylethenyl)-, [1S- $(1 \alpha, 2 \beta, 4 \beta)]-$ & 1096 & - & 0.51 & $\mathrm{C}_{15} \mathrm{H}_{24}$ & - \\
\hline 31 & 5,9-Undecadien-2-one, 6,10-dimethy 1-, $(E)$ - & 1133 & - & 0.11 & $\mathrm{C}_{13} \mathrm{H}_{22} \mathrm{O}$ & 194 \\
\hline 32 & Aromandendrene & 1113 & - & 0.33 & $\mathrm{C}_{15} \mathrm{H}_{24}$ & 204 \\
\hline 33 & $\beta$-Copaene & - & - & 0.11 & $\mathrm{C}_{15} \mathrm{H}_{24}$ & 204 \\
\hline 34 & Germacrene D & 1126 & - & 0.21 & $\mathrm{C}_{15} \mathrm{H}_{24}$ & - \\
\hline 35 & 1,3-Benzodioxole, 4-methoxy-6-(2-propenyl)- & 1151 & - & 18.08 & $\mathrm{C}_{11} \mathrm{H}_{12} \mathrm{O}_{3}$ & 192 \\
\hline 36 & Elemicin & - & - & 0.48 & $\mathrm{C}_{12} \mathrm{H}_{16} \mathrm{O}_{3}$ & 208 \\
\hline 37 & (-)-Globulol & 1152 & 3.68 & 2.94 & $\mathrm{C}_{15} \mathrm{H}_{26} \mathrm{O}$ & 222 \\
\hline 38 & Viridiflorol & 1155 & 0.85 & 1.16 & $\mathrm{C}_{15} \mathrm{H}_{26} \mathrm{O}$ & 222 \\
\hline 39 & Ledol & 1158 & - & 0.32 & $\mathrm{C}_{15} \mathrm{H}_{26} \mathrm{O}$ & 222 \\
\hline 40 & Eremophilene & 1159 & - & 0.21 & $\mathrm{C}_{15} \mathrm{H}_{24}$ & 204 \\
\hline 41 & $1 H$-Indene, 1-ethylideneoctahydro-7a-methyl-, cis- & 1181 & 0.49 & 0.41 & $\mathrm{C}_{12} \mathrm{H}_{20}$ & 164 \\
\hline 42 & tau.-Muurolol & 1165 & - & 0.16 & $\mathrm{C}_{15} \mathrm{H}_{26} \mathrm{O}$ & 222 \\
\hline 43 & $\beta$-Eudesmol & 1191 & 1.52 & 1.85 & $\mathrm{C}_{15} \mathrm{H}_{26} \mathrm{O}$ & 222 \\
\hline 44 & 2-Phenethyl- $\beta$-phenylpropionate & 1132 & - & 0.09 & $\mathrm{C}_{17} \mathrm{H}_{18} \mathrm{O}_{2}$ & 254 \\
\hline 45 & Diosgenin & - & - & 0.28 & $\mathrm{C}_{27} \mathrm{H}_{42} \mathrm{O}_{3}$ & 415 \\
\hline 46 & Methanone, cyclohexyl-1H-imidazol- 4-yl- & 1223 & - & 0.20 & $\mathrm{C}_{10} \mathrm{H}_{14} \mathrm{~N}_{2} \mathrm{O}$ & 178 \\
\hline 47 & Sesquicineole & 1190 & - & 0.33 & $\mathrm{C}_{15} \mathrm{H}_{26} \mathrm{O}$ & 222 \\
\hline 48 & Benzyl benzoate & 1207 & - & 0.09 & $\mathrm{C}_{14} \mathrm{H}_{12} \mathrm{O}_{2}$ & 212 \\
\hline 49 & 3-Isopropyl-6,7-dimethyltricyclo[4.4.0.0(2,8)]decane-9,10-diol & 1197 & - & 0.12 & $\mathrm{C}_{15} \mathrm{H}_{26} \mathrm{O}_{2}$ & 238 \\
\hline 50 & Isopropyl myristate & 1156 & - & 0.04 & $\mathrm{C}_{17} \mathrm{H}_{34} \mathrm{O}_{2}$ & 270 \\
\hline 51 & 2-Pentadecanone, 6,10,14-trimethyl- & 1133 & - & 0.28 & $\mathrm{C}_{18} \mathrm{H}_{36} \mathrm{O}$ & 268 \\
\hline 52 & 13-Tetradecen-1-ol acetate & 1196 & - & 0.05 & $\mathrm{C}_{16} \mathrm{H}_{30} \mathrm{O}_{2}$ & 254 \\
\hline 53 & 2,6,10,14,18-Pentamethyl-2,6,10,14,18-eicosapentaene & - & - & 0.06 & $\mathrm{C}_{25} \mathrm{H}_{42}$ & 342 \\
\hline 54 & Ethanone, 1-(7-hydroxy-5-methoxy-2,2-dimethyl-2H-1-benzopyran-8-yl)- & 1244 & - & 0.09 & $\mathrm{C}_{14} \mathrm{H}_{16} \mathrm{O}_{4}$ & 248 \\
\hline 55 & 1,2,5-Oxadiazol-3-amine, 4-(3-methoxyphenoxy)- & 1385 & - & 0.03 & $\mathrm{C}_{9} \mathrm{H}_{9} \mathrm{~N}_{3} \mathrm{O}_{3}$ & 207 \\
\hline 56 & Cyclohexanol, 2-[2-pyridyl]- & 1261 & - & 0.05 & $\mathrm{C}_{11} \mathrm{H}_{15} \mathrm{NO}$ & 177 \\
\hline 57 & Octadecane & 1194 & - & 0.07 & $\mathrm{C}_{18} \mathrm{H}_{38}$ & 254 \\
\hline 58 & Phytol & 1234 & - & 0.25 & $\mathrm{C}_{20} \mathrm{H}_{40} \mathrm{O}$ & 297 \\
\hline 59 & Eicosane & 1271 & - & 0.29 & $\mathrm{C}_{20} \mathrm{H}_{42}$ & 282 \\
\hline 60 & Tetracosane & - & - & 0.36 & $\mathrm{C}_{24} \mathrm{H}_{50}$ & 338 \\
\hline 61 & Di- $n$-decylsulfone & 1390 & - & 0.25 & $\mathrm{C}_{20} \mathrm{H}_{42} \mathrm{O}_{2} \mathrm{~S}$ & 346 \\
\hline
\end{tabular}




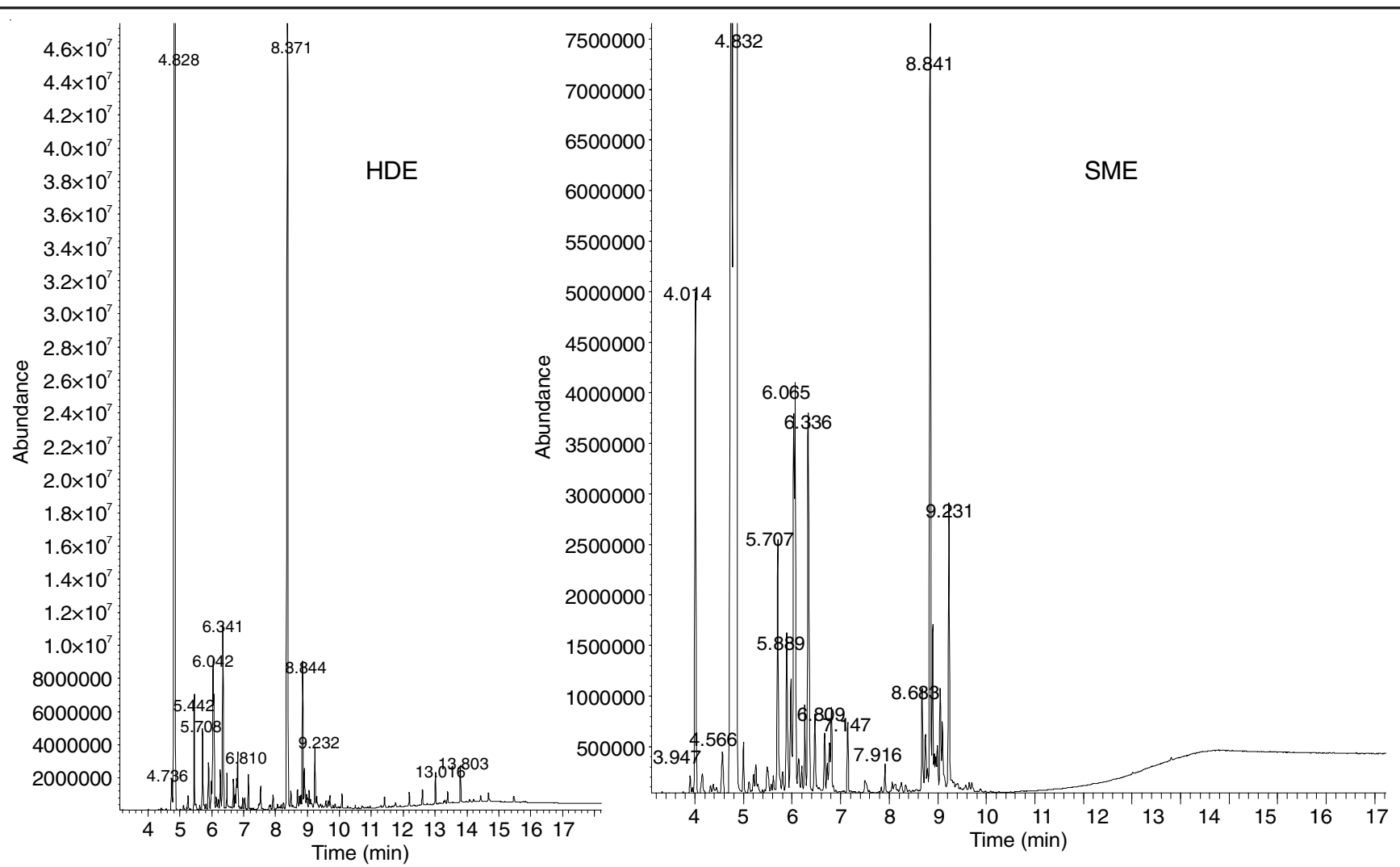

Fig. 1. Chromatography of Jatropha multifida essential oil by HDE and SME

(weight/dry weight), respectively. The major compound as observed is eucalyptol with 70.38 and $35.62 \%$ for SME and HDE, respectively. From the GC-MS analysis, the oil compositions were dominated by oxygenated compounds. Ketones such as 2-nonanone, 4-isopropenylcyclohexanone, D-carvone, pinocarvone were identified in the extracted oil. Oxygenated monoterpenes were the most important derivatives identified, mainly because of the high percentage of eucalyptus (SME, $70.38 \%$; HDE, $35.62 \%$ ) in the two extraction methods. The amount of total oxygenated obtained by SME and HDE are 87.53 and $79.34 \%$, respectively. Oxygenated monoterpenes were prevalent in contrast to monoterpenes hydrocarbons. The oils were also characterized by oxygenated sesquiterpenes (SME, $6.05 \%$; HDE, $7.34 \%$ ).
Other compounds identified in the oil include $\alpha$-pinene (SME, $2.64 \%$; HDE, $0.05 \%$ ), $\beta$-myrcene (HDE, $0.07 \%$ ), $o$ cymene (SME, $8.11 \%$; HDE, $0.85 \%$ ), 2-carene (HDE, 0.36 $\%$ ), aromandendrene (HDE, $0.33 \%$ ), $\beta$-copaene (HDE, 0.11 $\%$ ), germacrene D (HDE, 0.21) and eremophilene (HDE, 0.21 $\%)$. Some high molecular alkanes were also identified in the extracted oil: octadecane (HDE, $0.07 \%$ ), eicosane (HDE, 0.29 $\%$ ) and tetracosane (HDE, $0.36 \%$ ).

Some of the major chemical components identified in the essential oil of Jatropha multifida under this study areas shown in Fig. 2.

The medicinal importance of several aromatic members of the Jatropha species have been reported in many studies [28]. The oils from plants in the genus have been used tradi-<smiles>CC(C)C12CCC(C)(CC1)CO2</smiles>

Eucalyptol<smiles>CC1=CCC2CC1C2(C)C</smiles>

$\alpha$-Pinene<smiles>Cc1ccccc1C(C)C</smiles>
$o$-Cymene

1,3-Benzodioxole, 4-methoxy-6-(2-propenyl)-<smiles>C=C1CCC(C(=C)C)CC1</smilescis-p-Mentha-1(7),8-dien-2-ol<smiles>C=CCc1cc(OC)c2c(c1)OCO2</smiles><smiles>C=C1CCC[C@@]2([14CH3])CC[C@@H](C(C)(C)O)C[C@H]12</smiles><smiles>C[C@H]1CC[C@H](C)C1[C@H]1C2CC[C@](C)(O)[C@@H]21</smiles>

Glubulol<smiles>CC1=CCC(C(C)(C)O)CC1</smiles>

$\alpha$-Pinene

Fig. 2. Some chemical components identified in the essential oil of Jatropha multifida 
tionally as treatment for wounds and other skin diseases, as an antidote to snake bites, treatment of piles and cancer [29]. For the first time, this study assessed the composition of the essential oils from the leaves of Jatropha multifida obtained by two extraction methods using gas chromatography-mass spectrometry (GC-MS). It is interesting to point out that there are significant quantitative differences in the two methods, suggesting that methods of extraction strongly influence its chemical composition (Table-1). Previous studies have indicated that the type of extraction method for essential oils determines, to a large extent, the composition of the oils and by extension, their effectiveness for various medicinal applications $[29,30]$. Certain volatile compounds discover by some means of extraction may not be identifiable when other extraction methods are used. The studies conducted here are, therefore, necessary to give indication of the best extraction methods for different compounds present in the oil samples from Jatropha multifida.

An interesting finding from this study is the identification of a larger number of compounds in the oils extracted by hydrodistillation (60 components) as compared to the one obtained using solvent-free microwave extraction method (17 components). This large variation in number of different compounds identified may be ascribed to the wide difference in the amount of time allowed for the respective extraction processes to occur. Solvent-free microwave extraction was superior in terms of saving energy and as well in the extraction time (30 min, compared to $3 \mathrm{~h}$ in HDE). The shorter time employed is believed to bring about less considerable changes in essential oil composition. However, it is also worth noting that the short extraction times may limit the amount and number of different compounds identifiable in the oils extracted by this method.

The composition of the oil using the two extraction methods is dominated by oxygenated monoterpenoids [31]. In this study, solvent-free microwave was compared with hydrodistillation of essential oil from aromatic herbs and it was found that the microwave technique yielded an essential oil with higher amounts of valuable oxygenated compounds. This claim was also supported in the present work, in which total oxygenated compound was $87.53 \%$ in SME as compared with $79.34 \%$ for HDE. The higher percentage of oxygenated compounds in SME oil than in HDE oil could be related to the high-speed heating of polar substances by microwaves and to the smaller amount of water used, thereby preventing the decomposition of principal oxygenated compounds by thermal and hydrolytic reactions [32]. The lower amount of oxygenated components in HDE oil than in SME oil furthermore established the role of the amount of water in degradation of oxygenated compounds. Water, accelerates many reactions, especially those reactions via carbocation as intermediates. More so, the chemistry of terpenoids is associated to carbocations and their transformations occurred by carbocation intermediates. Monoterpenoids have been reported to be less valuable than oxygenated monoterpenes with regards to contribution to the fragrance of the oil [31].

The major compound obtained in the present work is eucalyptus with the SME having a higher percentage area than the HDE. Eucalyptus is an oxygenated monoterpene whose oil has been shown to possess a strong activity against several organisms [33]. The excellent usage of Jatropha multifida in the treatment of many ailments could be attributed to the presence of eucalyptus present in the plant.

Possible conversion reactions in essential oil components occur as a result of their structural association by oxidation, isomerization, cyclization or dehydrogenation reactions [34]. The monoterpene 1,3,8-p-menthatriene could be considered to have been converted to a set of monoterpene alcohols: trans$p$-mentha-2,8-dien-1-ol, trans- $p$-mentha-1(7),8-dien-2-ol and cis- $p$-mentha-1(7),8-dien-2-ol by possible hydration reaction taking place in the reaction mixture.

\section{Conclusion}

The present study devoted to assess the gas chromatography-mass spectrometry (GC-MS) composition of bioactive essential oils compounds from the leaves of Jatropha multifida by two extraction methods. The results of this work indicated that different methods of extraction produce variation in the essential oil compositions. The study may provide information on a suitable method of extraction of the essential oil for industrial application and may assist in the realization of essential oil as a natural source of plant and animal food additives. These various bioactive compounds in the essential oil may partially justify their use in folklore medicine.

\section{ACKNOWLEDGEMENTS}

The authors are thankful to Govan Mbeki Research \& Development Center, University of Fort Hare, Alice, South Africa for the funding of this work.

\section{CONFLICT OF INTEREST}

The authors declare that there is no conflict of interests regarding the publication of this article.

\section{REFERENCES}

1. W. Dhifi, S. Bellili, S. Jazi, N. Bahloul and W. Mnif, Medicines, 3, E25 (2016);

https://doi.org/10.3390/medicines3040025.

2. M. Hyldgaard, T. Mygind and R.L. Meyer, Front. Microbiol., 3, 12 (2012); https://doi.org/10.3389/fmicb.2012.00012.

3. P. Tongnuanchan and S. Benjakul, J. Food Sci., 79, R1231 (2014); https://doi.org/10.1111/1750-3841.12492.

4. C. Carvalho, L.V. Mariano, V.S. Negrão, C.P. Gonçalves and M.C.R. Marcucci, J. Anal. Pharm. Res., 7, 581 (2018);

https://doi.org/10.15406/japlr.2018.07.00286.

5. S. Rampadarath, D. Puchooa and V.M. Ranghoo-Sanmukhiya, Asian Pac. J. Trop. Med., 7, S380 (2014); https://doi.org/10.1016/S1995-7645(14)60262-5.

6. D.A. Akinpelu, O.A. Aiyegoro and A.I. Okoh, Afr. J. Biotechnol., 8, 1660 (2009).

7. World Agroforestry Centre (WAC), When Oil Grows on Trees, WORLD, (2009).

8. A. Adesola and O. Adetunji, The Internet J. Alternat. Med., 4, (2006).

9. B.S. Nayak and K.N. Patel, Int. J. Pharm. Res., 1, 35 (2009).

10. B. Dehgan, Proc. Annu. Meet. Fla. State Hort. Soc., 95, 277 (1982).

11. O.O. Aiyelaagbe, Fitoterapia, 72, 544 (2001); https://doi.org/10.1016/S0367-326X(00)00291-4.

12. J. Kayode and M.A. Omotoyinbo, J. Bot. (Faisalabad), 3, 107 (2008).

13. G. El Diwani, S. El Rafie and S. Hawash, Afr. J. Pharm. Pharmacol., 3, 521 (2009).

14. B. Das, K. Laxminarayana, M. Krishnaiah, Y. Srinivas and T.V. Raju, Tetrahedron Lett., 50, 4885 (2009); https://doi.org/10.1016/j.tetlet.2009.06.054.

15. O.O. Igbinosa, E.O. Igbinosa and O.A. Aiyegoro, Afr. J. Pharm. Pharmacol., 3, 58 (2009). 
16. https://en.wikipedia.org/wiki/Jatropha accessed on the 27th of October (2015).

17. L.S. Gills, Ethnomedical Uses of Plants in Nigeria, University of Benin Press: Nigeria (1992).

18. O.J. Hamza, C.J.P. van den Bout-van den Beukel, M.I.N. Matee, M.J. Moshi, F.H.M. Mikx, H.O. Selemani, Z.H. Mbwambo, A.J.A.M. Van der Ven and P.E. Verweij, J. Ethnopharmacol., 108, 124 (2006); https://doi.org/10.1016/j.jep.2006.04.026.

19. A. Falodun, V. Imieje, O. Erharuyi, A. Joy, P. Langer, M. Jacob, S. Khan, M. Abaldry and M. Hamann, Asian Pac. J. Trop. Biomed., 4, 374 (2014); https://doi.org/10.12980/APJTB.4.2014C1312.

20. B. Das, B. Ravikanth, K.R. Reddy, P. Thirupathi, T.V. Raju and B. Sridhar, Phytochemistry, 69, 2639 (2008); https://doi.org/10.1016/j.phytochem.2008.08.011.

21. B. Das, K. Laxminarayana, M. Krishnaiah, Y. Srinivas and T.V. Raju, Tetrahedron Lett., 50, 4885 (2009a); https://doi.org/10.1016/j.tetlet.2009.06.054.

22. R.P. Labadie, eds.: S.M. Colegate and R.J. Molyneux, Bioactive Natural Product, CRC Press: Boca Raton, Ann Arbor, London, Tokyo (1993).

23. B. Das, K.R. Reddy, B. Ravikanth, T.V. Raju, B. Sridhar, P.U. Khan and J.V. Rao, Bioorg. Med. Chem. Lett., 19, 77 (2009b); https://doi.org/10.1016/j.bmcl.2008.11.014.

24. S. Kosasi, W.G. Van Der Sluis, R. Boelens, L.A. Hart and R.P. Labadie, FEBS Lett., 256, 91 (1989); https://doi.org/10.1016/0014-5793(89)81724-7.

25. S. Kosasi, W.G. Van Der Sluis and R.P. Labadie, Phytochemistry, 28, 2439 (1989); https://doi.org/10.1016/S0031-9422(00)98000-2.
26. E. Kovats, Helv. Chim. Acta, 41, 1915 (1958); https://doi.org/10.1002/hlca.19580410703.

27. IUPAC, Retention Index, I in Column Chromatography, Compendium of Chemical Terminology, the Gold Book, edn 2 (1997).

28. C.W. Sabandar, N. Ahmat, F.M. Jaafar and I. Sahidin, Phytochemistry, 85, 7 (2013); https://doi.org/10.1016/j.phytochem.2012.10.009.

29. C.E.L. da Silva, S. Minguzzi, R.C.L. da Silva, M.F.C. Matos, D. Tofoli, J.E. de Carvalho, A.L.T.G. Ruiz, W.F. da Costa and E. Simionatto, $J$. Braz. Chem. Soc., 26, 233 (2015); https://doi.org/10.5935/0103-5053.20140253.

30. C.E.L., da Silva, W.F. da Costa, S. Minguzzi, R.C.L. da Silva and E. Simionatto, J. Anal. Methods Chem., 2013, Article ID 352606 (2013); https://doi.org/10.1155/2013/352606.

31. M.E. Lucchesi, F. Chemat and J. Smadja, J. Chromatogr. A, 1043, 323 (2004); https://doi.org/10.1016/j.chroma.2004.05.083.

32. M.E. Lucchesi, J. Smadja, S. Bradshaw, W. Louw and F. Chemat, J. Food Eng., 79, 1079 (2007); https://doi.org/10.1016/j.jfoodeng.2006.03.029.

33. A.K. Tyagi, D. Bukvicki, D. Gottardi, G. Tabanelli, C. Montanari, A. Malik and M.E. Guerzoni, BioMed Res. Int., 2014, 1 (2014); https://doi.org/10.1155/2014/969143.

34. C. Turek and F.C. Stintzing, Compr. Rev. Food Sci. Food Saf., 12, 40 (2013);

https://doi.org/10.1111/1541-4337.12006. 